\title{
Vladimir Nazor u recepciji studenta Ivana Merza
}

\author{
Božidar Nagy*
}

\begin{abstract}
Sažetak
Dvadesetogodišnji student Ivan Merz otkrio je veličinu Vladimira Nazora kao pjesnika i književnika za vrijeme Prvog svjetskog rata 1916. na počeku svojeg vojništva. Bilo je to u Slovenskoj Bistrici, kamo je bio poslan na časnički tečaj, gdje je susreo Nazorova prijatelja i suradnika Josipa Ribarića, jezikoslovca. Ribarić ga je potaknuo i oduševio za Nazora i njegova književna djela, koja je Merz čitao u slobodno vrijeme. Svoje dojmove o Nazorovim djelima Merz najprije priopćuje u pismima svojemu profesoru Ljubomiru Marakoviću. Istodobno u svojem ratnom dnevniku donosi prikaze Nazorovih djela koja je čitao te daje o njima svoje ocjene, mišljenje i pohvale. U ovom članku donose se uz uvodni komentar najvažniji citati iz pisama i dnevničkih zapisa Ivana Merza u kojima govori o Nazoru. Da se dobije kompletnija slika o Merzu, kao i o Nazoru, Merzovim tekstovima pridodali smo i navode o Nazoru iz Marakovićevih pisama upućenih Ivanu Merzu. Merz je bio oduševljen otkrićem Nazorove poezije i smatrao je Nazora kao pjesnika „hrvatskim velikanom“. Posebno je dojmljiva Merzova izjava da su „Hrvati slijepi što ne vide kako velikog pjesnika imaju, kao što je Nazor". Smatra da će tek nakon njegove smrti „vidjeti da je bio velikan“.

Ključne riječi: Ivan Merz, Vladimir Nazor, Ljubomir Maraković, Josip Ribarić, dnevnik, pisma
\end{abstract}

\section{Uvod}

Zanimanje za objektivniji i potpuniji pristup proučavanju književnog opusa i osobe velikog hrvatskog književnika i pjesnika Vladimira Nazora reanimiran je 2012. kada sam otkrio jedanaest do sada javnosti potpuno nepoznatih Nazorovih pisama Ljubomiru Marakoviću. ${ }^{1}$ Evo sasvim ukratko kako je došlo do tog ot-

* Prof. dr. sc. Božidar Nagy, Fakultet filozofije i religijskih znanosti, Sveučilište u Zagrebu. Adresa: Jordanovac 110, 10000 Zagreb, Hrvatska, E-pošta: bnagy@ffrz.hr

1 Ljubomir Maraković (Topusko, 1887. - Zagreb, 1959.), hrvatski književni i kazališni kritičar i povjesničar te istaknuti katolički intelektualac. Studij slavistike i germanistike završio je u Beču, gdje je 1909. doktorirao. U Beču je kao jedan od prvih članova Hrvatskog katoličkog pokreta četiri godine uređivao katolički časopis $L u c ̌$. Kao gimnazijski profesor službovao je u Banjoj Luci, gdje izvršio veliki vjerski i intelektualni utjecaj na Ivana Merza te pridonio njegovoj duhovnoj formaciji koja je za rezultat imala Merzovo proglašenje blaženikom Katoličke crkve 2003. godine. Nakon Banje Luke premješten je u Zemaljsku vladu u Sarajevo, gdje radi u odjelu za prosvjetu. 
krića. Branko Richter (1920.-2012.), nećak Ljubomira Marakovića, neposredno prije svoje smrti početkom 2012. godine predao je Marakovićevu pisanu ostavštinu i dokumente u Arhiv Postulature bl. Ivana Merza na trajno čuvanje. Pregledavajući kao postulator Ivana Merza zaprimljene dokumente, na veliko svoje iznenađenje našao sam među njima jedanaest autografskih pisama Vladimira Nazora, koja je on uputio svojemu prijatelju Ljubomiru Marakoviću, poznatomu hrvatskomu književnomu kritičaru, a koji je izbliza pratio Nazorov književni rad i o njegovim djelima donosio prikaze, recenzije i ocjene. Ta do sada potpuno nepoznata pisma, ukupno njih jedanaest, pisana su između 1926. i 1930. godine. U njima Nazor piše Marakoviću o svojem književnom radu, o svojim djelima, njihovu nastanku, ali i o njihovoj filozofsko-teološkoj pozadini, kao i o svojim religioznim uvjerenjima. Ta Nazorova pisma važan su doprinos poznavanju Nazorove osobe, njegova duhovnog profila, njegova religioznog uvjerenja i bacaju sasvim novo svjetlo na njegov svjetonazor. Budući da se radilo stvarno o senzacionalnom otkriću, odmah sam o tome obavijestio organizatore znanstvenog skupa Nazorovi dani, koji se svake godine održavaju u Nazorovu rodnom mjestu Postirima na Braču. Organizatori su me odmah pozvali da sudjelujem još iste godine na tom znanstvenom skupu. Tako sam 25. svibnja 2012. održao na Nazorovim danima svoj referat o tom otkriću i predstavio sam javnosti Nazorova pisma. Sljedeće godine ta sam Nazorova pisma uz svoj komentar objavio u časopisu za književnost Matice hrvatske (Nagy, 2013), a moj referat održan na Nazorovim danima 2012. godine objavljen je potom u Zborniku radova Nazorovi dani 2010. do 2015. pod naslovom Otkrivena nepoznata pisma Vladimira Nazora (Nagy, 2015).

Pismohrana između Nazora i Marakovića pisana između 1926. i 1930. otkriva nam osobu i svjetonazor Vladimira Nazora u drugačijem svjetlu nego što nam ga je prikazivao komunistički režim i njegova propaganda tijekom dugih godina komunističke vladavine. Iako je i u prethodnim desetljećima bilo radova koji su se bavili Nazorovom pjesničkom duhovnošću, imamo dojam da u književno-povijesnim pregledima i čitankama upravo ti radovi nisu mogli doći do svoje pune afirmacije. Ta Nazorova pisma vjerodostojno pokazuju njegovu dušu prožetu duhovnim i kršćanskim vrijednostima koje je unosio i u svoja djela i pjesme.

Pored toga drugačiji pogled prema Nazoru razotkriva se i u izdanju knjige njegovih religioznih pjesama pod naslovom Ja vjerujem, koju je priredio Nedjeljko Mihanović (Nazor, 2014).

U ovom članku ne donosim nešto novo iz Nazorove ostavštine, nego prikazujem jednu drugu nepoznatu građu, tj. do sada nepoznate činjenice iz života Ivana Merza povezane s pjesnikom Vladimirom Nazorom. Dva su izvora odakle sam crpio podatke i saznanja o toj temi. Prvi je Dnevnik Ivana Merza koji sam kao 4.

\footnotetext{
Nastavlja službu u Zagrebu i dva je desetljeća uređivao Hrvatsku prosvjetu. Sve do 1945. bio je aktivno uključen u vodstvu Hrvatskog katoličkog pokreta. Godine 1944. postao je profesor na Visokoj pedagoškoj školi u Zagrebu, ali ga je komunistički režim 1945. suspendirao kao profesora sa svih državnih učilišta. Poput tolikih drugih nevinih žrtava komunističkog režima i on je 1947. osuđen i zatvoren s dvogodišnjim gubitkom političkih prava. Od 1949. bio je profesor na Međubiskupijskoj gimnaziji u Zagrebu do mirovine (Lončarević, 2003).
} 
svezak njegovih Sabranih djela u cijelosti objavio 2014. te je dostupan javnosti. Međutim ono što predstavlja izvornu i do sada neobjavljeno arhivsko gradivo korespondencija je između Ivana Merza i njegova bivšeg gimnazijskog profesora Ljubomira Marakovića, u kojoj ima mnogo podataka o Vladimiru Nazoru. Upravo na temelju tog do sada neobjavljenog arhivskog gradiva te uz pomoć Merzovih dnevničkih zapisa mogao sam u ovom članku rekonstruirati do u detalje kako je Nazor svojim djelima utjecao na jednog mladog studenta književnosti koji, nakon što je otkrio Nazora kao vrsnog književnika i pjesnika i njime se oduševio, piše o njemu lijepe ocjene i kritike pronalazeći kroz njegove pjesme i djela puno toga zajedničkog pod umjetničko-književnim vidom. To se događa tijekom 1916. i 1917. godine. Merzu je bilo tada dvadeset godina (rođen je 1896.), a Nazoru četrdeset godina (rođen je 1876.). Do tada je Nazor već bio objavio oko četrnaest svojih djela i bio je u usponu svojeg književnog stvaralaštva.

Pogledajmo sada detaljnije kako je student Ivan Merz došao u kontakt s djelima Vladimira Nazora koja su za njega bila pravo otkriće.

\section{Merz otkriva pjesnika Nazora za vrijeme Prvog svjetskog rata}

Ivan Merz, rođen u Banjoj Luci 1896., završio je u svojem rodnom gradu gimnazijsko školovanje i položio maturu u srpnju 1914., svega dva tjedna prije izbijanja Prvog svjetskog rata. Nakon tromjesečnog boravka u Vojnoj akademiji u Bečkom Novom Mjestu, na kraju 1914. Merz upisuje na Bečkom sveučilištu najprije studij prava. Međutim, vrlo brzo prelazi na studij književnosti. Kako se rat rasplamsavao i Merz je pozvan u vojsku. Mobiliziran je u veljači 1916. i poslan na vojnu obuku najprije u Graz, a nakon toga upućen je na časnički tečaj u Slovensku Bistricu, gdje je ostao nekoliko mjeseci. Među polaznicima tečaja upoznao je Josipa Ribarića, ${ }^{2}$ osobnog prijatelja Vladimira Nazora. Premda je Merz već i prije odlaska u vojsku čitao neke Nazorove pjesme, o čemu obavještava svojeg prijatelja Nikolu Bilogrivića, tek u kontaktu s Ribarićem otkriva tog našeg slavnog pjesnika i njegova književna djela, koja ga počinju oduševljavati. O tome Merz opširno piše najprije svojemu profesoru Marakoviću, koji je dobro poznavao i Nazora, kao i Ribarića. Koliko je Merz bio oduševljen otkrićem Nazora, vidi se također i iz njegova ratnog dnevnika, u kojem na mnogo mjesta

2 Josip Ribarić (1880.-1954.), hrvatski jezikoslovac. Rođen je u Vodicama (Istra), školovanje završio na Sušaku, a studij slavistike u Beču. Kao profesor jezika radio je u Kastvu, Bujama i Poreču. Mobiliziran je u Prvom svjetskomu ratu, gdje susreće i Ivana Merza s kojim prijateljuje. Na književnom području surađuje s Vladimirom Nazorom. Napisao je studiju $O$ istarskim dijalektima. Nakon Prvog svjetskoga rata u izaslanstvu je države SHS kao ekspert za Istru i sudjeluje na Mirovnoj konferenciji u Parizu 1919. godine. Nastavlja rad na kulturnom i književnom području. Nakon svršetka Drugog svjetskog rata komunistička mu je vlast uskratila mirovinu. Godine 1948. odaziva se pozivu Bože Milanovića te na sjemenišnoj gimnaziji u Pazinu predaje hrvatski jezik. Dolazi 1950. u Zagreb, gdje je sudjelovao u više projekata Instituta za jezik JAZU, među ostalim u izradbi Rječnika JAZU (Merz, 2014, 204, bilj. 10). 
tijekom 1916. godine donosi prikaze i ocjene Nazorovih djela koja je čitao za vrijeme pohađanja časničkog tečaja u Slovenskoj Bistrici.

Pored zapisa u dnevniku, Merz šalje književne dojmove o Nazoru i svojemu gimnazijskomu profesoru Ljubomiru Marakoviću, s kojim je i nakon završetka gimnazije ostao u pismenom kontaktu tijekom rata i potom za vrijeme daljnjeg studija u Beču i Parizu. Ljubomir Maraković kao književni kritičar budno je pratio književno stvaralaštvo Vladimira Nazora i o njemu je pisao pozitivne kritike, a bio je s Nazorom i u pismenom kontaktu, kao što smo već spomenuli na početku ovog članka.

Da bi se dobila cjelovita slika o Merzovoj recepciji Nazora, njegove dnevničke zapise nadopunili smo dijelovima iz Merzove korespondencije s Ljubomirom Marakovićem.

U tekstovima Merzova dnevnika uočava se kako Merz u Nazorovim pjesmama nalazi puno sličnosti sa svojim nutarnjim duševnim svijetom. Tako navodi čak jednu Nazorovu pjesmu u cijelosti koja je odgovarala tadašnjemu njegovu duševnomu raspoloženju. Posebno je važna ova njegova tvrdnja iz jednog pisma upućenog Marakoviću: »No, uglavnom budi rečeno da sam po Novim pjesmama vidio da je Nazor mnogo toga stvorio za čim sam težio« (HR-AIM. Pismo Lj. Marakoviću, Slov. Bistrica, 15. svibnja 1916.). Dakle, u Nazorovim pjesmama Merz vidi ostvarenje svojih književnih aspiracija, vidi srodnost svoje i njegove duše pod književno-umjetničkim vidom.

Međutim, prvi spomen na Nazora i njegove pjesme nalazimo u jednoj karti koju je Merz uputio svojemu prijatelju, inače sarajevskomu studentu teologije, Nikoli Bilogriviću još početkom 1916.: »Dragi Nina! [...] Nazorovih pjesama imade dosta lijepih u novom izdanju. Poslat ću Ti po koju, dok dospijem « (HR-AIM. Dopisnica N. Bilogriviću, Banja Luka, 30. siječnja 1916.). Dakle već mjesec dana ranije, prije nego je krenuo u vojsku, Merz je čitao neke Nazorove pjesme koje su mu se bile svidjele pa to odmah želi podijeliti sa svojim velikim prijateljem s kojim je bio stalno u pismenom kontaktu sve do završetka studija. Međutim pravo otkriće Nazora kao velikog pjesnika uslijedilo je za Merza tek nekoliko mjeseci kasnije, za što je zaslužan Ribarić, inače Marakovićev kolega sa studija u Beču.

Najprije donosimo, i to kronološkim redom, dijelove iz Merzovih pisama Ljubomiru Marakoviću, a potom u sljedećem poglavlju tekstove iz dnevnika Ivana Merza u kojima govori o Nazoru. U prvom dijelu navodimo i nekoliko izvadaka iz pisama Marakovića Ivanu Merzu u kojima govori o Nazoru kako bismo dobili cjelovitu sliku Merzova otkrića veličine Nazora kao književnika, a u što je uvjeren i Maraković, kako je razvidno iz njegovih pisama Merzu.

\section{Tekstovi Ivana Merza o Nazoru u pismima Ljubomiru Marakoviću}

Prije nego je počeo zapisivati u svoj dnevnik dojmove i potom prikaze te ocjene Nazorovih djela, Merz je o svojem otkriću Nazora kao pjesnika najprije obavijestio svojeg gimnazijskog profesora Ljubomira Marakovića i s njime je podijelio radost tog otkrića. U mnogim dopisnicama i pismima koja mu šalje iz vojske tijekom 1916. i 1917. govori o Nazoru. Za bolje razumijevanje načina kako 
je Merz obavještavao Marakovića treba spomenuti da su vojnici koji su bili mobilizirani u austrougarskoj vojsci tijekom Prvog svjetskog rata mogli slati svojoj rodbini i prijateljima samo otvorene poštanske karte-dopisnice, što se odnosilo i na Merza. Ako sadržaj poruke nije mogao stati na jednu kartu, nastavilo se pisati na dvije ili tri karte, već prema tome koliko je trebalo. Tako se u ostavštini Ivana Merza sačuvalo nekoliko stotina njegovih karata upućenih roditeljima i prijateljima, među njima i njegovu profesoru Marakoviću. Veoma rijetko Merz je uspio napisati i poslati redovnom poštom pokoje opširnije pismo, pogotovo Marakoviću.

U prvoj karti koju Merz upućuje Marakoviću 10. travnja 1916., a u kojoj počinje pisati o Nazoru, nalazimo najavu opširnijeg lista u kojem će mu poslati zanimljive informacije o pjesniku. Spominje nastanak pojedinih pjesama iz zbirke Pjesni ljuvene te posebice kako je Nazor bio radostan Marakovićevom ocjenom zbirke Hrvatski kraljevi: »Čim dospijem javit ću Vam opširno vrlo zanimljive podatke o Nazoru; osobe koje su inspirirale Pjesni ljuvene, kako su one nastale, te znam mnoge detalje o nastanku njegovih pjesama. Nadalje, pjesnike koje on uvijek čita (Pascoli!) i kako je bio sav udivljen kada je pročitao Vašu ocjenu Hrvatskih kraljeva.«(HR-AIM, Slov. Bistrica, 10. travnja 1916.)

U sljedećoj dopisnici koju upućuje Marakoviću već nakon četiri dana vidimo kako je Merz u vojsci bio zaokupljen i intelektualnim svijetom poezije te kako je s prof. Ribarićem raspravljao o Nazoru: » Na straži sam. U kasarni ponoćna tišina, a petrolejska svjetiljka na mom stolu svijetli... Ovdje su Suljić, Atijas, Belančić i Zechner. Onda profesor Ribarić. S njim raspravljamo o Nazoru.« (HR-AIM, Slov. Bistrica, 14. travnja 1916.)

Nakon mjesec dana, 15. svibnja 1916. Merz upućuje Marakoviću najavljen opširan izvještaj o Nazoru i njegovim djelima što je doznao od prof. Ribarića. Odmah na početku pisma naglašava kako ga je sada zaokupio studij Nazora. Posebno je važno naglasiti da na kraju tog opširnog pisma Merz dotiče temu religije u Nazorovim pjesmama i to veoma pozitivnim riječima. I još jednu važnu konstataciju pri kraju pisma Merz ističe: Nazor je »mnogo toga stvorio za čim sam težio«. Drugim riječima, nalazi puno sličnosti između sebe i Nazora u odnosu na književno stvaralaštvo, u čemu ga je Nazor, stariji od njega dvadeset godina, pretekao. U nastavku donosimo najvažnije dijelove iz opširnog pisma o Nazoru što ga je Merz najavio i poslao Marakoviću:

Već se odavno bavim mišlju jednoga pisma koji bi Vam imao prikazati svijet u kojemu se krećem, moju duševnu borbu i koji bi Vas informirao o mnogim zanimljivim predmetima [...].

Mene je sada zaokupio studij Nazora; a pošto znam koliko ga Vi cijenite i kako ćete se zanimati za svaku sitnicu iz njegova života, to ću Vam nešto malo o njemu ispripovijedati. No ponajprije bih Vam htio reći što je svratilo moju pozornost na nj. Dakle ab ovo!

Čim sam prispio ovamo zalazio sam često u društva, znajući da ću naići na raznovrsne vrste ljude. Tako se i zbi[...]. No najviše me je razveselilo prijateljstvo s Ribarićem, Nazorovim prijateljem (kojega Vi poznajete još iz univerzitetskih godina). Ne mogu reći, da me je on upozorio na ljepote toga pjesnika; ali on je bio povodom da sam naumio Nazora prostudirati. Najzgodnija prilika! I pošto znadem toliko zanimljivosti 
iz života i iz djela toga hrvatskog velikana, osjećam upravo neku unutarnju potrebu da Vama - mome literarnom majstoru — nešto priopćim.

Vi ste jamačno opazili kako se Nazor nakon svoje Lirike počeo služiti novom tehnikom. Ribarić ga je naime oko 1910. upozorio na Pascolija, u kojega se slog riječi slaže s ritmom. Ukratko: Nazor je tada prekinuo sa starom školom i stao upotrebljavati Pascolijevu tehniku. No, pošto Nazor — kao i ostali Dalmatinci — ne poznaju prave naglaske riječi, naručio si je Broza, Ivekovića, Pavića i druge rječnike i stao studirati poput Hugoa i mnogih drugih pjesnika — jezik i naglaske. Istom sada se je on zapravo zaljubio u hrvatski jezik i uvijek misli kako bi se izdao kakav popularni rječnik koji bi na popularan način upozorio na jezične ljepote. O ritmici dosta, iako bih imao dosta da pričam o ritmu iz Intime, no dok sve potankosti ne prostudiram, neću se nabacivati rastrganim fragmentima.

No sada dolazi tema koja će Vas — kao stara bibliotekara — osobito zanimati: a to je Nazorova biblioteka. Tu su, uz rječnike, francuska antologija, Aida, Cavalleria rusticana, Faust, veliki Faust koga za vrijeme cijelog svog života studira, Heineovi Nordsee (Talata u novim pjesmama) i — što sam već davno zaključivao po Intimima — Selma (Christus legenden). (O filozofiji se još ne dospjeh informirati). O njegovoj narodnoj ideji možete si stvoriti sud već po Novim pjesmama, a i po onoj u Život i Dva gleda, koji se odnose na Srbe. Doduše on to gleda sa mnogo višeg stanovišta, nego li se je to do sada činilo [...].

Pa kad je Ribarić već govorio o njegovim poznanicima, tu dolazite i Vi u obzir. Kad mu je onda - u ono slavno doba — donio Ribarić Luč s Vašom ocjenom Hrvatskih kraljeva, bio je sav ushićen i govorio: „Ha, taj me je jedini do sada razumio.“

Noćca se spušta, valja skratiti. Nazor živi gore u Kastvu u svojoj turris eburnea, daleko od svijeta i njegova blata; kao pravi asketa (Dva gleda u Pjesnima ljuvenim, pokazuje kako je seksualno netaknut). Rijetko, 2-3 puta godišnje silazi u Rijeku ili Opatiju. Njegova stara mati i sestra ga dvore. Profesor Šepić i Ribarić su još s njim. To je sve. Posljednji mu pomaže kod filoloških pitanja: recimo ona čakavska pjesma Žena zapušćena je uglavnom plod te dvojice [...].

Dakle: Nazor živi osamljeno, pravilno i dnevno šeće nekoliko sati u toj sjajnoj prirodi. $S$ jedne strane se vidi Velebit, s druge Učka, a dolje more: Nazorovo more! Oslonjen na štap ide on svuda; gleda on kako se magle uz stijene veru i stane kod svake dolinice i svakog grmića u kojemu je najmanje jedan slavuj. I taj orkestar je — po Ribarićevu pričanju — nešto izvanredno. Osim toga se je nedavno dogodilo da se je snijeg preko noći otopio, a onda najednom udarila bura, tako da se je sva šuma kano kristal sledila. (Točan opis u Kristalnoj šumi).

No netko drugi se je digao na tu Planinu sanja i toga diva poluboga — poput Lohengrina - opet učinio običnim smrtnikom. To bijaše gospođa Brovetova — žena dakle, koju je poput slavuja u Notturnu (Nove pjesme) mamio, koju je u duši nazrijevao (kako veli u Pjesnima ljuvenim) - došla je. Žena je jednoga liječnika koji je naukovac. Osobite je inteligencije, zanima se za botaniku. S njom je Nazor šetao, katkada u prisustvu učiteljice Zahije, pače — čudo neviđeno! — Nazor ju je jedanput pozvao na ručak. I to je sve: o ljubavi jamačno nijesu nikada govorili. No, ona kano da je također duboko osjetila tu ljubav, utekla je odavle na svoje ostrvce (Izgubljeni raj). Plod te duboke ljubavi su Pjesni ljuvene. Time završavam svoj kratki referat o Nazoru; kad ga budem cijeloga prostudirao, poslat ću Vam već plodove toga, no uglavnom budi rečeno, da sam po Novim pjesmama vidio, da je on mnogo toga stvorio za čim sam težio. Što se tiče njegove religije: tu je sličan Hugou. Silan optimist, duševni kontrast Kranjčeviću. Na Vrhu u Novim pjesmama on izriče svoju religiju. Za kršćansku etiku je dušom 
i tijelom, a silno štuje estetsku stranu kulta Madoni, koji toliko uljepšava život Hrvata. Zato mu se i osobito dopada jedna Pascolijeva pjesma gdje je opisana svibanjska pobožnost. (HR-AIM, Pismo Ivana Merza Marakoviću, Slov. Bistrica, 15. svibnja 1916.)

U sljedećoj dopisnici Merz iznosi informaciju o Nazorovu trenutačnom književnom stvaralaštvu, što svjedoči kako on trajno prati Nazorove književne produkcije. » Ribarić mi je pričao o Nazoru da će skoro biti preveden cijeli Pakao od Dantea. Spjevao je jedan romantički ep (Utva zlatokrila) i jednu Märchendramu. Pjesama dosta [...].«(HR-AIM, Slov. Bistrica, 30. svibnja 1916.)

Sljedeći ulomak donosimo iz pisma što ga je Maraković napisao Merzu. Iz njega možemo zapaziti da ni Maraković nije bio suglasan s kritičkim osvrtima i tumačenjima Nazora od strane književnika Grgeca.

Htio sam pisati o Nazoru, ali me je pretekao Grgec u Hrvatskoj Prosvjeti. Naravski da se ne slažem s onakvim načinom prikazivanja, ali ja ne dospijem na sve, pa moram gledati kako drugi batale ono što ja tek polagano mogu da gradim. [...] Srdačna Vam hvala na podacima, sve me je do kraja veoma interesiralo [...]. Nazora ne puštam s vida. Možda je baš dobro, što se ne mogu sada njime baviti: pribrat ću više materijala […]. (HR-AIM, Sarajevo, 14. lipnja 1916.)

I u trenutcima napornog vojnog pješačenja i opasnih mjesta bojišnih terena Merz je u mislima nosio sjećanje na Nazora i njegove pjesničke vrline:

Vani huje bijesni vjetri, frcaju oblaci kano zmije, [...] Gore sam u planini u domaji Burnsa i Nazora, u kolijevci Mahometova pijeva (Goethe!) i svih genija... Prošli smo opasnih mjesta. Tu noćimo. Sutra idemo natrag u Mürrzuschlag. Mnogo sam sakupio materijala. Studirao sam Nazora i sada me interesiraju estetska pitanja: Psalmi Whitman — Rodin. (HR-AIM, Dopisnica, Rax-Dolomiti, 21. kolovoza 1916.)

U pismu Merzu Maraković navodi planove za studij Nazora: »Od srca Vam hvala na svemu: i na Vašem čestom sjećanju, i na oduševljenju sa vrhunca Raxa — ne znate, koliko me sve to raduje. «U nastavku Maraković piše o svojim neposrednim planovima u koje ubraja i studij Nazora: »Kanim napisati Nazor i kritika $=$ resumé njegovih zadnjih radova na temelju dosadašnjih kritika koje su izašle.« (HR-AIM, Dopisnica Merzu, Sarajevo, 23. rujna 1916.)

Merz obavještava u sljedećoj dopisnici Marakovića o Nazorovim planovima za osnivanje novog književnog lista.

Istom sam danas zapravo našao pravo vrijeme da temeljitije pročitam Vaš list. Velite da mislite reformirati Prosvjetu ili eventualno osnovati kakav novi list. Ne znam jesam li Vam već rekao da i Nazor na tome radi pa bi bilo zgodno dogovoriti se s njime. Po Ribarićevu pričanju imao bi taj list okupiti oko sebe sve talente (bez razlike stranaka!) itd. (HR-AIM, Seewiesen, 13. prosinca 1916.)

U sljedećem pismu Marakoviću Merz komentira Nazorovu Utvu zlatokrilu i hvali njegovu pjesničku veličinu:

Utvu zlatokrilu pročitao sam prije 2-3 mjeseca, pa se sjećam da sam našao dosta tehničkih nedostataka. Inače je za nas zaista krasna stvar, a što je glavno prvi pravi romantičko-idilički epos. Trebalo bi napisati kakav esej o Nazoru; šteta je, da se naši velikani upoznavaju istom poslije njihove smrti. (HR-AIM, Dopisnica, Seewiesen, početak 1917.) 
Vrlo je zanimljiv sljedeći Merzov zapis, u kojem pruža kratak, ali jasan kritički sud o onima koji ne znaju cijeniti Nazora. Također je vidljivo vrlo dobro Merzovo zapažanje neplodonosnog kritikanstva, razvijanja narcisoidnosti i zlobnih prigovora koji su se razvijali unutar hrvatske književne kritike, a nerijetko su se kritičari tog razdoblja znali više baviti međusobnim antagonizmima, negoli temeljitom, nepristranom i stručno argumentiranom kritikom.

Primio sam Hrvatsku Prosvjetu, Vrhbosnu, Grič, a danas mi Čičić posla i Našu misao. Na poslanim listovima hvala. Prosvjeta mi se ni malo ne sviđa; (...) Vidi se nekakav čudan egoistični duh u Prosvjeti gdje svaki hoće da bude originalan i pametan, pa razara i ono što je u nas najbolje (ocjena Utve Zlatokrile). Namjesto da smo sretni, da imamo Nazora, Krizmana, ovakvi mali budalaši idu napadati. (HR-AIM, Dopisnica, Zingarella, 10. travnja 1917.)

U sljedećem odlomku Maraković izražava divljenje nad velikom energijom Nazorova stvaralaštva i objavljivanjem novih knjiga pa obavještava Merza o najnovijim Nazorovim izdanjima: »Izišli su Pabirci od Nazora, a za koji dan će i Mrtvo ostrvo (Istarska priča). Prosto ga čovjek ne može stići! (HR-AIM, Dopisnica, Sarajevo, 1. lipnja 1917.)

\section{Tekstovi Ivana Merza o Nazoru u Dnevniku}

U ovom drugom dijelu tekstova Ivana Merza o književniku Vladimiru Nazoru donosimo najvažnije njegove dnevničke zapise iz razdoblja rata dok je boravio na časničkom tečaju u Slovenskoj Bistrici. Svakomu tekstu prethodi kratak uvodni komentar. Ti su zapisi duži nego u korespondenciji s Marakovićem, a sadrže prikaz Nazorovih djela koja je tada Merz čitao. Tu su i njegove analize, ocjene i mišljenja o njima te tako upotpunjuju sve ono što je Merz pisao u svojim dopisima Marakoviću. U Merzovu dnevniku Nazor je prisutan od 14. travnja do 31. listopada 1916., a u korespondenciji s Marakovićem taj je period veći i obuhvaća cijelu godinu, od 10. travnja 1916. do 10. travnja 1917. godine.

U prvom dnevničkom zapisu od 14. travnja 1916. u kojem Merz spominje Nazora uočavamo kako je Merz iz razgovora s Ribarićem došao do pojedinih podataka o zbiljskim događajima koji su nadahnuli Nazorove ljubavne pjesme. Zapis također odražava Merzovo visoko moralno shvaćanje međuljudskih emocionalnih odnosa, ali i njegovu erudiciju poznavanja Nazorovih romanističkih uzora i pjesničkih srodnika.

Veseli me što sam naišao na prof. Ribarića, jednog seniora i dobroga prijatelja Nazora. Naravski, sav se razgovor vrti oko toga našega velikog pjesnika. Pripovijeda mi o njegovom asketskom načinu života i o realnoj podlozi njegovih pjesama. Pjesni ljuvene imaju realnu podlogu. Muž gospođe Brovetove je u vojsci. Ona je češće dolazila u Kastav na razgovor i to jednoj staroj učiteljici. Eto, kako je bila inteligentnija gospođa zanima se botanikom, a inače zgodna. Gledao bi Nazor potajice na nju. „Sto mislite, taj asketa je gospođu Brovetovu jednom s tom gospodičnom pozvao na ručak." A i inače su se šetali — no nikada sami. I to bijaše sve. Ona je otišla tamo valjda na Krk i oni se nikada neće vidjeti. (Sjeća ta ljubav na Werthera, pa i na Immensee). Nevješto oko ne bi ništa opazilo; no Nazor je mnogo toga proživio. Plod toga su pjesme. Treba- 
le bi se analizirati te pjesme, pa imamo pred sobom Nazora. Osobito je lijepa pjesma gdje joj veli da se nikada sastati neće, no misliti će jedno na drugo. Ribarić misli da je ona mnogo dublje tu ljubav proživjela. Običan čovjek bi se usrećio; no tragična je sudba pjesnika što je on viši od običnih ljudi i poput Mojsija (Vigny) teži za običnom ljudskom srećom, no u svojoj veličini i osamljenosti ostaje nesretan.

S formalne strane došao je Nazor na nagovor Ribarićev do uvjerenja da se ritam mora slagati s naglaskom riječi. Takove su pjesme u zbirci Intima. Možda je zato tako brzo pristao jer je i Pascoli u Italiji od te škole; a ovoga on osobito voli. Ta, Nazor je prije talijanski pjevao nego li hrvatski. Poema Kristalna šuma je fakat. God. 1913. je to bilo u blizini Kastava. Sjevernjak udario, sva voda se na drveću smrzla da je šuma bila poput stakla, prozirna, kristalna blistajući se u duginim bojama. (Merz, 2014, 204-205)

U sljedećem fragmentu zapažamo iskaze u kojima se Ivan Merz divi Nazorovoj pjesničkoj ekspresiji i hvali jezik Nazorovih pjesama.

S Ribarićem čitam Nazora i sada se istom uživljujem u našu poeziju; dolazim sve više do uvjerenja kako je naš jezik divan, samo kad dođe u dobre ruke. A takve su Nazorove. Da nam je Nazor dao samo svoj jezik sa svojim epitetima učinio bi mnogo. No, uz to se je on digao na Planinu sanja iznad svake strančanosti i podao nam u svojim pjesmama svoj duboki duševni život. Drugom prilikom ću o njemu napisati studiju. (Merz, 2014, 207)

Nakon dva tjedna Merz opet bilježi u svojem dnevniku kako nastavlja proučavati Nazora: »Nazora nadalje proučavam« (Merz, 2014, 208).

Unutar odabranih odlomaka možemo uočiti da je Merz iskristalizirao jasan i visok estetski sud prema pjesniku te je smatrao Nazora pjesničkim velikanom kojim se Hrvati trebaju ponositi.

Malo sam se danas razvedrio čitajući Nazorove Istarske priče. Nisam znao da u $\mathrm{Hr}-$ vata ima tako modernih i lijepih pripovijesti koje mogu u mnogom pogledu stupati usporedo sa Lagerlöfovima. Faktično Hrvati su slijepi; ne vide kakvu veliku kulturnu epohu proživljuju, kako velikog pjesnika imaju, kao što je Nazor. Kada on umre, istom onda će vidjeti da je bio velikan.

Nije on pjesnik koji živi u gradu osamljen, koji poput Verlaina zbog kontrasta s društvom dolazi do tako dubokih čuvstava. Ne, on podsjeća na Pindara i druge, koji su izolirani od društva i žive na visini, gdje sebi stvaraju svoj svijet i iz visine promatraju prošlost i sadašnjost naroda, a utiru put budućnosti. Zato vidimo da je epska nota u njegovoj lirici; da to nisu opisi čuvstva jednog individua koji u društvu stvara, koji živi i ljubi poput ostalih ljudi, nego je to neki Homer, Mojsije, svećenik naroda, koji nam u poeziji daje svoje dojmove o prirodi, svoju filozofiju o njoj, te filozofiju svoga naroda...

U Istarskim pričama Nazor nama dade krasne opise Istre, s historijskim dobom Kastavskih vitezova i Creskih vlastela, koji dolaze u prošnju na svojim galijama. Tu su krasni opisi šume i Kastava sa svojim dolima i slavujima, te opis kako neki „car planina" svira uz diple. Opisi mora i mjesečine sa svim nijansama, jedne noći à la Walpurgis jest čega dosada nema u hrvatskoj literaturi. (Merz, 2014, 208-209)

U sljedećem odlomku prisutan je prikaz, pohvala, ali i mala kritička primjedba Nazorovoj pripovijesti Facol rakamani.

Facol rakamani... Jasno se vidi da ova pripovijest nije nastala iz dublje duševne potrebe, kao što je Göste, ${ }^{3}$ nego je pjesnik tako veliki umjetnik da s lakoćom imitira stil

3 Pripovijest Selme Lagerlöff. 
Selmin, ${ }^{4}$ boje Canticuma Canticoruma,${ }^{5}$ mistiku Strindberga, a uporaba minerala i mirisa bilinskoga je kao u Wildea. Prema tome se nalaze u ovoj noveli dva dosta nezgodno pomiješana elementa koja bi za se mogla dati dvije raznovrsne novele. [...] Opis šume u pripovijesti. To je nešto sasvim drugo nego što je to uradio prozaični Kozarac u svojoj Slavonskoj šumi. Tu živi svaka trava, svaki hrast, ma sve miriše i cvijeta. Onda je more sa svim svojim sinjim detaljima u svim časovima, osobito za vrijeme mjesečine najbolje u hrvatskoj literaturi. Uz to i romantički detalji, iako je to zapravo Walpurgisnacht — dovedeni su u sklad s hrvatskom tradicijom (snaše...). Ona ljubavna očitovanja, čežnja muža k ženi i obratno isto kao u velepjesmi, zapravo je divotna imitacija te Salomonove knjige, ${ }^{6}$ samo što mi se čini da je prijelaz suviše goropadan, pa suviše jasno upada u oči kako je to umetnuto u djelo.

Osobiti čar — kako već rekoh — podaje djelu ono naivno promatranje života kano u basni; ona usporedba dragulja i drugih konvencionalnih no karakterističnih izraza iz bajke (usta kao rubini i slično). Uskrišenje kulturne historije, doba kastavskog kapetana, creskog vlastelina i čobana Divljana na način basne kao u Selme je lijepo. Čovjeku se nameće zapravo želja da Nazor napiše neku Istrijadu — kao što je Gösta Wermlandijada - gdje će u formi tih Märchenerzählungena iscrpsti sve strane istarskog života. (Merz, 2014, 209-210)

U sljedećem odlomku Merz brani Nazora od uspoređivanja s Fichetom, što mu se čini neprikladnim, te nastoji svoje mišljenje podrobnije argumentirati. Posebno uočava u njegovim pjesmama evoluciju prema kršćanstvu i kršćanskoj etici.

Nazorova zbirka Intima pokazuje jednu lijepu evoluciju kršćanstvu. Od onog Kiklopa, klasičnog užitka u vedrini i ljubavnom nagonu prirode, do onog misticizma u Glasu i mnogim drugima (pače već jako u Novim pjesmama) jest možebitni nehotičan prijelaz kršćanskoj etici.

Ono što Grgec ${ }^{7}$ veli u Hrvatskoj Prosvjeti o „fichteovcu“ Nazoru to je odviše površan sud. Ta i on znade, kako čovječja duša - pa i najkatoličkijeg čovjeka - nije jednostavna i primitivna. U njoj sve uvijek traje boj „svjetla i mraka“ (Pjesni ljuvene) i mnogo je mučniji posao u svojoj duši braniti osvojeno kršćanstvo nego li uspeti se na taj vrh. Pa ako jednom pjesniku dođe neki šus — ta to se i nama često dogodi — pa se razveseli kad nađe u Reklamovoj Povijesti filozofije o Fichteu koji veli da mi jedino opstojimo, a ostalo je samo sjena, prikaza, varka - nije čudno da on to odmah obradi; ta koliko je puta Nazor to osjetio. Moj svijet $^{8}$ nije zaista njegov nazor o životu, jer bi on sam sebi bio najvećim protuslovljem:

4 Selma Lagerlöff (1858.-1940.), švedska književnica, dobitnica Nobelove nagrade za književnost 1909. godine, čime je postala prva žena koja je dobila to priznanje za svoj literarni rad (Krleža, 1967, s. v. Lagerlöf, Selma).

5 Starozavjetna knjiga Pjesma nad pjesmama.

6 Za Pjesmu nad pjesmama prije se smatralo da ju je napisao kralj Salomon.

7 Petar Grgec (1890.-1962.), profesor, hrvatski književnik i katolički javni radnik. Školovao se u Travniku, a studirao u Zagrebu. U studenskim danima bio je urednik časopia Luč i Hrvatska prosvjeta. Poslije završetka studija uređuje Riječke novine, Narodne novine i Seljačku omladinu. Od 1921. član je društva sv. Jeronima. Bio je organizator i jedan od ideologa Hrvatskog katoličkog pokreta. Objavio je brojna djela i pjesme. Dolaskom komunističkog režima na vlast bio je osuđen na dugu robiju zbog svojeg vjerskog i hrvatskog rodoljubnog uvjerenja (Kovačec, 2002, s. v. Grgec, Petar).

8 Pjesma iz Nazorove zbirke Intima. 
„Kad ću, kad ću jednom jak i dobar moći

da međ ljude siđem iz te kule svoje?"

Pa zašto bi on silazio, kad on jedino postoji?!

(Merz, 2014, 210-211)

Nazorova pjesma Pred raskršćem imala je velik odjek u Merzovoj duši. U svojem ratnom dnevniku mladi dvadesetogodišnji Ivan Merz veoma često piše, razmatra i raščlanjuje problem ljubavi. Tematiku ljubavi susreće u književnim djelima koja je čitao, a i u svakodnevnom životu se s njome susreće. Promatrajući svojeg prijatelja i njegovu zaručnicu, koja mu je bila simpatična i uočio je kod nje velike duševne kvalitete, navodi u svojem dnevniku cijelu Nazorovu pjesmu Pred raskršćem iz zbirke Pjesni ljuvene (1915.). U toj je pjesmi našao izraz svojeg tadašnjeg duševnog stanja pa ispred pjesme stavlja ovu uvodnu rečenicu:

Ova Nazorova pjesma, kano da je u ovome času za me spjevana:

„Ona jaka, kobna, ne, ti bila nisi,

Što će dušu moju, ko iz praćke kamen,

Zavitlat u tamu il' u sunčev plamen:

Jedino me tugom nadojila ti si.

$\mathrm{Ne}$, ti nisi ona, kojoj sv'jetli znamen

Na mom nebu stoji, pa sve moje klisi

Prema znaku, što mi iznad glave visi:

Svjetla, što ga čekam, bila si tek pramen.

Jedino me tugom ti si nadojila;

I taj bol, ko crni talas plodne sile,

Prodr'o mi nije u najtanje žile

Svjetla, što ga čekam, tek si tračak bila.

I taj tračak nije bio sjajan dosti,

Da mi sja bar jednom stazom beskrajnosti.“

(Merz, 2014, 214)

Iz sljedećeg odlomka navodimo daljnje Merzove informacije o Nazorovu trenutačnom književnom radu, ali uočavamo i jednu širinu Merzova pogleda prema različitim vizurama i modalitetima pjesničkih realizacija.

Ribarić je bio kod Nazora. Veli da je napisao romantički epos Utva zlatokrila, što će se čitati mjesto Kohan i Vlaste. Uz to Snježanu — čini mi se Märchenspiel. No najviše se bavi prijevodom Pakla (Dante) i to u jambima, a na kraju daktil (svečano nešto za kor!). Bavi se mišlju da osnuje literarni list poput Marconija u Firenzi koji će okupiti sve sile bez razlike nazora o svijetu. Mislim da je to zgodno, jer zaista Hrvatska Prosvjeta kao i estetski dio Luči (zapravo isto!) suviše zalaze u strančarska pitanja (starčevićanci, nacionaliste) i primaju samo proizvode katolika, namjesto da okupe sve stvari — pa makar i od panteista — koje su dobre; jer nema čovjeka, koji nesvjesno ne misli u mnogome katolički. (Merz, 2014, 214-215)

I dolazimo do posljednjeg spomena Nazora u dnevniku Ivana Merza. Samo kratko navodi da je pročitao Nazorovu Utvu zlatokrilu: »Pročitao sam također Nazorovu Utvu zlatokrilu, [...] romantičko-idilički epos« (Merz, 2014, 231).

O Nazoru bit će još spomena u korespondenciji između njega i Marakovića sve do 10. travnja 1917. godine. Nakon toga datuma Merz ga više nigdje ne spominje. Možemo bez pretjerivanja zaključiti da je tim svojim tekstovima, kako u 
svojem dnevniku tako i u korespondenciji s Marakovićem, Merz podignuo dostojan spomenik Nazoru u svojoj pisanoj ostavštini.

\section{Zaključak}

Čitajući tekstove Ivana Merza o Nazoru ostajemo zadivljeni kako je jedan mladić od samo dvadeset godina tako zrelo i pronicavo donosio tako vrijedne i meritorne sudove o našem pjesniku. Nazor je na Merza utjecao najprije u književno-umjetničkom, a potom i nacionalno-rodoljubnom smislu. Ako usporedimo tekstove o Nazoru s ostalim piscima i njihovim djelima koja je Merz analizirao u svojem dnevniku, možemo zaključiti da je Nazor jedan od rijetkih autora o kojem Merz piše oduševljeno i u superlativima. Nazor je kroz svoja djela nedvojbeno pridonio razvoju Merzove književne kulture i umjetničkog osjećaja za ljepotu prirode, profinjenosti nutarnjih osjećaja te buđenju nacionalne svijesti i ljubavi prema svojem narodu, njegovoj povijesti i tradiciji.

U tekstovima Ivana Merza koje smo donijeli i analizirali vidjeli smo da je u središtu Merzove pozornosti Nazorovo stvaralaštvo pod književno-umjetničkim vidom. Religiozne sadržaje u Nazorovim djelima spominje samo usput i to na dva mjesta. Prvi je razlog činjenica da je sam Merz 1916. u svojem duhovnom razvoju bio još u periodu tzv. „estetskog katolicizma“, kako je sam definirao taj predratni dio svojeg života. Njegovim interesnim područjem dominirala je književnost pod umjetničkim vidom pa su i religiozni sadržaji bili tomu podređeni. Nakon što se upoznao s Nazorom i njegovim djelima, bio je na početku svojeg vojništva i još nije doživio rat u svoj svojoj ozbiljnosti, dramatičnosti, trpljenju, kao što se dogodilo nekoliko mjeseci kasnije nakon što je upućen na talijansko bojište, gdje proživljava sve ratne strahote i neprestano živi u smrtnoj opasnosti. Nakon sudjelovanja u ratu njegov pogled na svijet se mijenja. Nestaje „estetski katolicizam“, a na prvo mjesto dolazi kršćanska vjera sa svojim vrijednostima. Na život i svijet Merz od tada gleda samo u svjetlu kršćanskih istina. Književnost i umjetnost od tada promatra samo ukoliko su povezane s religioznim vrijednostima i njima podložne. Odatle i izbor teme za doktorsku disertaciju Utjecaj liturgije na francuske pisce, koju je uspješno napisao i obranio na Sveučilištu u Zagrebu 1923. godine.

S druge strane, treba svakako naglasiti da do 1916. godine Nazor još nije napisao svoja najljepša djela s kršćanskim sadržajima u kojima je izrazio svoja vjerska uvjerenja. Spomenimo samo najvažnija: Zbirka pjesama o Četiri arhanđela (1927.), autobiografske novele Legenda o sv. Kristoforu (1922.) i Anđeo u Zvoniku (1926.), autobiografska pjesma Božić (1926.), Vjesnik (1927.) Od posljednje pjesme Vjesnik jedan dio je uzet kao himan u hrvatskom prijevodu Časoslova Božjega naroda (svećenički brevijar). Možemo si tek zamisliti kakvim bi superlativima Merz obasuo Nazora i njegovo stvaralaštvo da su mu došle do ruku spomenute Nazorove pjesme i novele. Umjesto njega to je puno godina kasnije učinio biskup Mijo Škvorc, i sam pjesnik, koji je za Nazorovu pjesmu Vjesnik rekao 
da je ona »vrhunac hrvatske religiozne lirike u kojoj je sadržana sva mariologija!« (Nazor, 2014, 157, bilj. 10).

Nije poznato ni igdje zapisano da su se Merz i Nazor osobno susreli, a bili su suvremenici. Za vrijeme dok je Nazor bio u Zagrebu od 1918. do 1920. Merz je bio na studiju u Beču. Kad se Merz vratio sa studija iz Pariza u Zagreb 1922. Nazor je živio i službovao na Sušaku i u Crikvenici. Posljednji spomen o Nazoru Merz donosi u svojem pismu Marakoviću od 10. travnja 1917., gdje brani Nazora i njegovo djelo od neutemeljenih napada i još jednom potvrđuje njegovu veličinu kao pjesnika.

Nakon rata i studija u Beču i Parizu duhovno-intelektualni i kulturni razvoj Ivana Merza išao je drugim smjerom. Već je to naznačio pri kraju rata u svojem dnevniku kada piše: »Moram započeti novi, preporođeni život u duhu novospoznatog katolicizma « (Merz, 2014, 299). Završivši studij u Parizu Merz se vraća u Zagreb, gdje je započeo aktivan život na raznim područjima. Tu su bile najprije njegove profesionalne dužnosti kao profesora na Nadbiskupskoj gimnaziji, potom aktivni rad u Hrvatskoj orlovskoj katoličkoj organizaciji, uvođenje papinske Katoličke akcije, promicanje liturgijskog pokreta itd. Nije imao više ni vremena baviti se umjetničko-književnim radom, kao što je to činio prije rata u periodu svojeg „estetskog katolicizma“.

U svojim ranim mladenačkim godinama formiranja, traženja i građenja osobnosti Merz se u izvjesnom smislu identificirao s Nazorom kad kaže da je »po Novim pjesmama vidio da je Nazor mnogo toga stvorio za čim sam težio« (HRAIM. Pismo Marakoviću, Slov. Bistrica, 15. svibnja 1916.). U svim tekstovima o Nazoru koji se nalaze u korespondenciji s Marakovićem i u svojem dnevniku, Merz smatra Nazora „hrvatskim velikanom“. A posebno je zanimljiva i dojmljiva Merzova tvrdnja kad kaže: »Faktično Hrvati su slijepi; ne vide kako velikog pjesnika imaju kao što je Nazor. Kada on umre, istom onda će vidjeti da je bio velikan« (Merz, 2014, 208).

Kao što nam je poznato iz Merzova doktorata, književna umjetnost, a posebice ona vjerskog nadahnuća, imala je veliki udio u intelektualnom i duhovnom formiranju lika blaženog Ivana Merza, a pritom je i Nazorovo umjetničko stvaralašto ostavilo u njemu svoj svijetli i plemeniti odraz.

\section{Literatura:}

Kovačec, August (ur.) (2002). Hrvatska enciklopedija: 4: Fr-Ht. Zagreb: Leksikografski zavod Miroslav Krleža.

Krleža, Miroslav (ur.) (1967). Enciklopedija Leksikografskog zavoda: 3: Heliodor — Lagerlöf. Zagreb: Jugoslavenski leksikografski zavod.

Lončarević, Vladimir (2003). Luči Ljubomira Marakovića: Život i rad. Zagreb: Filozofskoteološki institut Družbe Isusove.

Maraković, Ljubomir (1927). Pjesme o četiri arhanđela. Hrvatska prosvjeta, 14(7-8), $145-149$.

Merz, Ivan (2014). Sabrana djela: Svezak 4.: Dnevnik. Zagreb: Postulatura za kanonizaciju bl. Ivana Merza - Filozofski fakultet Družbe Isusove - Glas Koncila.

Mihanović, Nedjeljko (2014). „Oteli su mi ga živa i oteli su mi ga mrtva!“: Kako je Vladimir Nazor „otišao“ u partizane i kako je umro? - Intervju. Glasa Koncila, 53(16), 19. 
Mihanović-Salopek, Hrvojka (1996). Nazorova mistična poezija u kontekstu hrvatske himnodijske tradicije. Mogućnosti, 43(10-12), 294-298.

Nagy, Božidar (2013). Otkrivena nepoznata pisma Vladimira Nazora. Kolo: časopis za književnost Matice hrvatske, 23(3-4), 224-241.

Nagy, Božidar (2015). Otkrivena nepoznata pisma Vladimira Nazora. U: Andrija Biličić (ur.), Zbornik radova znanstvenog skupa Nazorovi dani 2010. do 2015. (str. 114-133). Postira: Osnovna škola Vladimira Nazora.

Nazor, Vladimir (2014). Ja vjerujem: Poezija religioznog nadahnuća. Priredio Nedjeljko Mihanović. Zagreb: Glas Koncila.

Rados, Zvjezdana (1994). U početku bijaše Božićni dar: (Prva Nazorova novela). Glasje, $1(1), 42-49$.

Žigo, Lada (2015). Nepoznati Vladimir Nazor: Od poganina do kršćanina. Vijenac, 23(561-562) 15 .

Arhivsko gradivo:

HR-AIM. (Arhiv Ivana Merza u Zagrebu) Korespondencija Ivana Merza i Ljubomira Marakovića. Ratni period.

Vladimir Nazor and his Reception by Ivan Merz, the Student

Božidar Nagy*

\section{Summary}

The twenty-year-old student, Ivan Merz, discovered Vladimir Nazor's greatness as a poet and writer during World War I in 1916 at the beginning of his engagement in military service. At the time he was in Slovenska Bistrica, where he was dispatched to receive officer training and where he met Nazor's friend and associate, Josip Ribaric, a linguist. Ribaric encouraged him to read Nazor's literary works - which he did in his free time - and Merz was amazed by them. He communicated his impressions of Nazor's works firstly in his letters to his professor, Ljubomir Marakovic. At the same time, he also wrote presentations in his war diary dealing with the works that he had read, giving his personal evaluations, opinions and conferring commendations. This article presents, along with an introductory commentary, the most significant quotes from the letters and diary of Ivan Merz concerning Nazor. For a more complete picture of Merz, and of Nazor as well, we added quotes about Nazor from Maraković's letters to Merz. Merz was thrilled by the discovery of Nazor's poetry and considered the poet Nazor a "Croatian prodigy". Particularly impressive is Merz's remark that "Croats are blind to the greatness of this man of letters, their very own Nazor". He felt that only after his death would people "see that he was a great man."

Key words: Ivan Merz, Vladimir Nazor, Ljubomir Maraković, Josip Ribarić, diary, letters

* Professor Božidar Nagy, Ph.D., Faculty of Philosophy and Religious Studies, Address: Jordanovac 110, 10000 Zagreb, Croatia, E-mail: bnagy@ffrz.hr 